\title{
Life history, patchy distribution, and patchy taxonomy in a shallow-water invertebrate (Mollusca: Polyplacophora: Lepidopleurida)
}

\author{
Julia D. Sigwart ${ }^{1,2} \cdot$ Chong Chen $^{3}$
}

Received: 15 February 2016 /Revised: 7 March 2017 / Accepted: 19 March 2017 / Published online: 8 April 2017

(C) The Author(s) 2017. This article is published with open access at Springerlink.com

\begin{abstract}
Things without names are difficult to rationalise, and so species that go without names are difficult to conserve or protect. This is a case study in resolving conflicts in historical taxonomy and 'real' species (identifiable and evolutionarily relevant groupings) using an approach including population genetics, natural history, and pragmatism. We report the observation that populations of a shallow-water chiton species from Washington and British Columbia demonstrate extremely high site fidelity and patchy distribution. Their limited dispersal potential and isolation could be explained by a brooding life history. This stands in direct contrast with the supposedly wide distribution of this "species", Leptochiton rugatus (Carpenter in Pilsbry, 1892) sensu lato, from the Sea of Japan to Baja California. But this lineage has previously been suggested to comprise several cryptic species. Indeed, a haplotype network analysis using 61 individual sequences of the cytochrome oxidase $\mathrm{c}$ subunit I gene
\end{abstract}

Communicated by V. Urgorri

This article is registered in ZooBank under urn:lsid:zoobank.org: pub:A5CD7021-089C-4494-B0CA-875FB64F72ED

Julia D. Sigwart

j.sigwart@qub.ac.uk

1 Marine Laboratory, Queen's University Belfast, 12-13 The Strand, Portaferry, Northern Ireland

2 Museum of Paleontology, University of California, Berkeley, VLSB 1101, Berkeley, CA 94720, USA

3 Department of Subsurface Geobiological Analysis and Research (D-SUGAR), Japan Agency for Marine-Earth Science and Technology (JAMSTEC), 2-15 Natsushima-cho, Yokosuka, Kanagawa 237-0061, Japan for L. rugatus s.l. revealed four discrete clusters which correspond to different parts of the geographic range. We infer these to represent four distinct species, at least two of which are likely novel. Leptochiton rugatus sensu stricto is herein reinterpreted as restricted to California and Baja California, and the new name L. cascadiensis sp. nov. is established for the lineage with a distribution in the Cascadia coastal bioregion from the panhandle of Alaska to Oregon. There are minor morphological differences among these species in the L. rugatus species complex, but genetic data or morphological observations alone would not have been sufficient to definitively recognise these groups as species-level lineages. The observation that different species within the complex may have different life history strategies provides important support for interpreting different populations as genuinely separate species.

Keywords Chiton · Cryptic species · Haplotype network · Life history $\cdot$ Northeast Pacific

\section{Introduction}

Genetic information has repeatedly revealed higher levels of first-order diversity than traditional morphological assessment. In most cases, genetic differences prompt a re-examination of previously overlooked morphological variation, which reveals "pseudocryptic" assemblages differentiated by these emergent features (Knowlton 1993). But molecular evidence, like some morphological evidence, may not be sufficient in isolation to make a taxonomic determination, especially when dealing with one gene region or one character (Riedel et al. 2013). Overlooked differences are found to correlate with historical hypotheses about species, representing additional taxonomic names that have been consigned to obscurity as junior 
synonyms. These synonymies have been flagged as a key bottleneck in quantifying global species richness (Costello et al. 2013a), a problem that needs to be addressed through concerted efforts by taxonomic experts. It is presently unclear to what extent the number of available names in synonymy balances the number of global marine species left undescribed.

Polyplacophoran molluscs (chitons) have a reputation as a taxonomically "difficult" group. In particular, the genus Leptochiton GRAY, 1847 is well known to be paraphyletic; although key features clearly separate more than 120 accepted living species, no characters have been identified that can be used to diagnose supraspecific groups (Sigwart et al. 2011). Many species of the genus Leptochiton are known from deepsea habitats, but several species are known from shallow water, including the North Pacific Leptochiton rugatus (Carpenter in Pilsbry, 1892). This species (complex) ranges from the Sea of Japan across to Alaska, down the coast of North American to Baja California (Kaas and Van Belle 1985). It is anecdotally recognised as representing potentially multiple distinct species (e.g. Vendrasco et al. 2012). Previously published population genetics results recovered two distinct 'populations' (Kelly and Eernisse 2007), but these were never applied to taxonomic revision, and taxonomic features suitable for distinguishing these apparently cryptic species have not been reported.

One often overlooked aspect of the identification of novel species is the importance of basic natural history observations. Life history information is often unavailable or undocumented for marine invertebrate taxa, even those in the accessible intertidal (Knowlton 1993). Yet key features of reproduction and feeding can provide important insight, particularly into the connectivity of natural populations.

We report an example of a cryptic species complex, describing one new species and noting the presence of two additional lineages that remain unresolved. In this case, morphological or molecular differences alone would not have been sufficient to recognise species-level lineages, but new observations of brooding behaviour in one population and the inferred limitation on dispersal in the group shed new light on these animals.

\section{Materials and methods}

Leptochiton rugatus sensu lato lives in low intertidal and subtidal depths, typically on the underside of stones partially buried in sand. Previous observations of populations in Washington, USA, and British Columbia, Canada, indicated that local populations of this species in that part of its range have extremely high site fidelity, and small patches $\left(<1 \mathrm{~m}^{2}\right)$ can reliably be re-collected over a span of at least a decade. Such patches appear sparsely distributed in the intertidal, but their true density is not well understood and is likely more abundant in the subtidal. For example, a population at a site in Sooke,
British Columbia, adjacent to a specific prominent intertidal boulder, has been home to a population continuously since at least 1986 (JDS, pers. obs. and museum records, last observation 2013). Field observations herein were recorded from specimens collected on 17 July 2012 from a population in False Bay, San Juan Island, Washington, USA $\left(48.57^{\circ} \mathrm{N} 123.17^{\circ} \mathrm{E}\right)$.

To examine the potential genetic differences among the Leptochiton aff. "rugatus" species complex, we assembled all available published COI sequences attributed to Leptochiton rugatus sensu lato and species that resolved within the L. rugatus clade in previous analyses (Sigwart et al. 2011; Sigwart 2016), and added sequences from two intermediate populations in Washington and Oregon, USA. These 61 sequences (Table 1) represent specimens from Russia, Alaska, British Columbia, Washington, Oregon, California, and Mexico. We used TCS version 1.21 software (Clement et al. 2000) to reconstruct statistical parsimony haplotype networks from a 362-bp alignment of the COI gene. The connection probability was set to $95 \%$, and sequences differing only by ambiguous characters were treated as the same haplotype.

Museum specimens of Leptochiton rugatus sensu lato from the collections in Naturalis (Leiden, the Netherlands; RMNH) were prepared by dissecting valve elements and radula, soaking in bleach to remove tissue, and rinsing thoroughly in $\mathrm{dH}_{2} \mathrm{O}$ before mounting on carbon adhesive and imaged using a scanning electron microscope (JEOL JSM-6480, Naturalis) at $15 \mathrm{kV}$.

\section{Taxonomy}

Class Polyplacophora Gray, 1821

Order Lepidopleurida Thiele, 1910

Leptochitonidae Dall, 1889, sensu lato

Leptochitonidae 'Clade I' Sigwart et al., 2011

Leptochiton Gray, 1847

Leptochiton cascadiensis sp. nov.

Figures $1 \mathrm{~d}-\mathrm{i}, 2$

Leptochiton cancellatus : Whiteaves 1887:113, 125; Newcombe 1893: 56; Berry 1927: 160; Berry 1951: 215, 218.

Lepidopleurus cancellatus : Dall 1921: 186; Oldroyd 1927: 246.

Leptochiton rugatus (partim) : Ferreira 1979: 147; Kaas and Van Belle 1985: 85.

Leptochiton sp.: Kelly and Eernisse 2007: appendix 1.

Leptochiton rugatus : Sigwart et al. 2011: fig 1B; Lamb and Hanby 2005; Carey et al. 2012: fig 1D; Carey 2014: appendix B; Layton et al. 2014; Sigwart et al. 2014: figs 2, 3, 8, tables 2-3; Sumner-Rooney et al. 2014.

? Leptochiton sp. : Dell'Angelo et al. 2011.

non Leptochiton alascensis : Layton et al. 2014: table S2.

Leptochiton rugatus 2 : Sigwart 2016: figs 1-2, appendix 1. 
Table 1 Previously published and new COI sequences in the Leptochiton rugatus species complex, analysed and illustrated in Fig. 3 (AMNH-AMCC, American Museum of Natural History Ambrose Monell Cryo Collection; CASIZ, California Academy of Sciences,
Invertebrate Zoology; MCZ, Museum of Comparative Zoology, Harvard University; SBMNH, Santa Barbara Museum of Natural History; ZSM, Bavarian State Collection of Zoology, Munich)

GenBank

Taxon in GenBank

Russia: Ussuriysky Bay, Sea of Japan; 2-4 m

Leptochiton sp. 2

ZSM (det. B. Sirenko)

HQ907868

L. rugatus

Russia: Vostok Bay; 2-2.5 m

Leptochiton sp. 2

ZSM (det. B. Sirenko)

HQ907869

L. rugatus

USA: Alaska: Cook Inlet

Leptochiton sp. 1

Layton et al. 2014

KF643833

KF643833

L. alascensis

Layton et al. 2014

USA: Alaska: Cook Inlet: Sitka County: Magic Island Beach

Leptochiton cascadiensis

Leptochiton cascadiensis

Leptochiton cascadiensis

Leptochiton cascadiensis

Canada: Haida Gwaii, BC

Leptochiton cascadiensis

Leptochiton cascadiensis

AMNH-AMCC 144538 / SBMNH 95358

AMNH-AMCC 144539 / SBMNH 95359

AMNH-AMCC 144540 / SBMNH 95360

AMNH-AMCC 144541 / SBMNH 95361

Layton et al. 2014

Layton et al. 2014

Canada: Vancouver Island, BC: Bamfield: Deer Group, Seapool Rocks

Leptochiton cascadiensis

Leptochiton cascadiensis

Leptochiton cascadiensis

Leptochiton cascadiensis

Leptochiton cascadiensis

Leptochiton cascadiensis

Leptochiton cascadiensis

AMNH-AMCC 144564 / SBMNH 89447

AMNH-AMCC 144566 / SBMNH 89446

AMNH-AMCC 144567 / SBMNH 89449

AMNH-AMCC 144568 / SBMNH 89453

AMNH-AMCC 144569 / SBMNH 89452

AMNH-AMCC 144570 / SBMNH 89451

AMNH-AMCC 144571 / SBMNH 89450
USA: San Juan Island, Washington: Edwards Reef

Leptochiton cascadiensis

Leptochiton cascadiensis

Leptochiton cascadiensis

USA: San Juan Island, Washing

Leptochiton cascadiensis

Leptochiton cascadiensis

Leptochiton cascadiensis

Leptochiton cascadiensis

Leptochiton cascadiensis

Leptochiton cascadiensis

Leptochiton cascadiensis

USA: Washington: Cape Alava

Leptochiton cascadiensis

Leptochiton cascadiensis

Leptochiton cascadiensis

Leptochiton cascadiensis

Leptochiton cascadiensis

Leptochiton cascadiensis

Leptochiton cascadiensis

Leptochiton cascadiensis

CASIZ 220237

AMNH-AMCC 141528

AMNH-AMCC 141529

AMNH-AMCC 141530

AMNH-AMCC 141531

AMNH-AMCC 141532

AMNH-AMCC 141533

AMNH-AMCC 141534

AMNH-AMCC 141535
AMNH-AMCC 135879 / SBMNH 355699

AMNH-AMCC 135880 / SBMNH 355698

AMNH-AMCC 135998 / SBMNH 95378
EF200729

EF200746

EF200730

EF200731

KF644284

KF643777

EF200740

EF200741

EF200742

EF200732

EF200743

EF200744

EF200748

EF200733

EF200727

EF200745

KY706109

KY706110

KY706111

KY706112

KY706113

KY706114

KY706115
EF200734

EF200735

EF200749

EF200736

EF200737

EF200738

EF200747

EF200728
L. alascensis

L. rugatus

L. rugatus

L. rugatus

L. rugatus

L. rugatus

L. rugatus

L. rugatus

L. rugatus

L. rugatus

L. rugatus

L. rugatus

L. rugatus

L. rugatus

L. rugatus

L. rugatus

L. rugatus

L. cascadiensis

L. cascadiensis

L. cascadiensis

L. cascadiensis

L. cascadiensis

L. cascadiensis

L. cascadiensis

L. rugatus

L. rugatus

L. rugatus

L. rugatus

L. rugatus

L. rugatus

L. rugatus

L. rugatus 
Table 1 (continued)

\begin{tabular}{|c|c|c|c|}
\hline Species & Specimen number or origin & GenBank & Taxon in GenBank \\
\hline Leptochiton cascadiensis & AMNH-AMCC 141536 & EF200739 & L. rugatus \\
\hline \multicolumn{4}{|c|}{ USA: Oregon: Cape Arago area, North Cove } \\
\hline Leptochiton cascadiensis & & KY706116 & L. cascadiensis \\
\hline \multicolumn{4}{|c|}{ USA: California: Monterey County: Monterey Breakwater } \\
\hline Leptochiton rugatus s.s. & AMNH-AMCC 115801 / SBMNH 94942 & EF200712 & L. rugatus \\
\hline Leptochiton rugatus s.s. & AMNH-AMCC 115802 / SBMNH 94943 & EF200709 & L. rugatus \\
\hline Leptochiton rugatus s.s. & AMNH-AMCC 115803 / SBMNH 94944 & EF200710 & L. rugatus \\
\hline Leptochiton rugatus s.s. & AMNH-AMCC 115804 / SBMNH 94945 & EF200717 & L. rugatus \\
\hline Leptochiton rugatus s.s. & AMNH-AMCC 115805 / SBMNH 94946 & EF200722 & L. rugatus \\
\hline Leptochiton rugatus s.s. & AMNH-AMCC 115806 / SBMNH 94947 & EF200725 & L. rugatus \\
\hline Leptochiton rugatus s.s. & AMNH-AMCC 115807 / SBMNH 94948 & EF200726 & L. rugatus \\
\hline Leptochiton rugatus s.s. & AMNH-AMCC 115808 / SBMNH 94949 & EF200723 & L. rugatus \\
\hline Leptochiton rugatus s.s. & AMNH-AMCC 115809 / SBMNH 94950 & EF200713 & L. rugatus \\
\hline \multicolumn{4}{|c|}{ USA: California: San Luis Obispo County: Kenneth S. Norris Rancho Marino Reserve } \\
\hline Leptochiton rugatus s.s. & AMNH-AMCC 144422 & EF200719 & L. rugatus \\
\hline Leptochiton rugatus s.s. & AMNH-AMCC 115778 / SBMNH 94937 & EF200705 & L. rugatus \\
\hline Leptochiton rugatus s.s. & AMNH-AMCC 115779 / SBMNH 94938 & EF200706 & L. rugatus \\
\hline Leptochiton rugatus s.s. & AMNH-AMCC 115814 / SBMNH 94940 & EF200711 & L. rugatus \\
\hline Leptochiton rugatus s.s. & AMNH-AMCC 115815 / SBMNH 94939 & EF200707 & L. rugatus \\
\hline Leptochiton rugatus s.s. & AMNH-AMCC 144362 / SBMNH 93540 & EF200724 & L. rugatus \\
\hline Leptochiton rugatus s.s. & AMNH-AMCC 144363 / SBMNH 93543 & EF200703 & L. rugatus \\
\hline Leptochiton rugatus s.s. & AMNH-AMCC 144364 / SBMNH 93544 & EF200721 & L. rugatus \\
\hline Leptochiton rugatus s.s. & AMNH-AMCC 144365 / SBMNH 93541 & EF200708 & L. rugatus \\
\hline Leptochiton rugatus s.s. & AMNH-AMCC 144421 / SBMNH 93539 & EF200720 & L. rugatus \\
\hline \multicolumn{4}{|c|}{ USA: California: Los Angeles County: Rancho Palos Verdes, Abalone Cove } \\
\hline Leptochiton rugatus s.s. & AMNH-AMCC 141754 / SBMNH 94655 & EF200718 & L. rugatus \\
\hline Leptochiton rugatus s.s. & AMNH-AMCC 144468 / SBMNH 94914 & EF200715 & L. rugatus \\
\hline Leptochiton rugatus s.s. & AMNH-AMCC 144469 / SBMNH 95323 & EF200716 & L. rugatus \\
\hline \multicolumn{4}{|c|}{ Mexico: Baja California: La Bocana } \\
\hline Leptochiton rugatus s.s. & AMNH-AMCC 141637 / SBMNH 93672 & EF200714 & L. rugatus \\
\hline Leptochiton rugatus s.s. & AMNH-AMCC 141636 / SBMNH 95000 & EF200704 & L. rugatus \\
\hline
\end{tabular}

ZooBank Registration urn:Isid:zoobank.org: act:C2A56C97-5C13-4708-ABAF-A3DF63A6A960 Type material

Holotype (CASIZ 220236) and 7 paratypes (CASIZ 220237)

\section{Type locality}

Near Snug Harbor, San Juan Island, Washington, USA, Friday Harbor: 48.571 N, 123.174 W.

\section{Etymology}

"From Cascadia", in reference to the biogeographical region and possible proposed country that constitutes the range of this species.

\section{Distribution}

North America: coastal waters of Alaska, British Columbia, Washington, and Oregon. 


\section{Diagnosis}

Animal small, elongate oval, moderately elevated, not carinated, not beaked, back and side slopes evenly rounded. Head valve semicircular, posterior margin with central notch. Intermediate valves densely sculptured with small granules distributed in longitudinal rows in central area and radiating rows on lateral areas. Anterior and posterior margins straight, lateral areas not inflated. Apophyses broad, trapezoidal. Granules with one central megalaesthete and six micraesthetes. Tail valve mucro anterior postmucronal slope straight. Radula with long, thin unicuspid major lateral tooth, major uncinal tooth long and slender, similar in width to major lateral, central tooth prominent with narrow blade, first lateral teeth tall ridges, not well defined as separate units. Gills 7 per side. Foot colour variable from cream to pink.

\section{Description}

Holotype $\sim 7.5 \mathrm{~mm}$ long. Shell not carinated, evenly rounded, moderately elevated (elevation ratio 0.36 in valve III of the holotype), valves not beaked. Colour tegmentum white to cream-coloured, some specimens with small patches of dark mineral deposit (Fig. 2).

Head valve slightly less than semicircular, wider than tail valve. Intermediate valves rectangular, lateral areas not inflated, anterior margins nearly straight, except margin of valve II convex, posterior margins straight. Tail valve with mucro anterior of centre, postmucronal slope straight or slightly convex.

Tegmentum of central areas and antemucronal area with subtle fine lines of fused granules (approx. $50 \times 40 \mu \mathrm{m}$, less elongate in lateral areas), about 30 ribs per side in intermediate valves. Ribs becoming slightly more widely spaced toward jugum; on distal pleural areas, ribs continue straight and terminate at lateral area.

Each granule with one megalaesthete $(6 \mu \mathrm{m}$ diameter $)$ surrounded by $4-6$ slightly smaller micraesthetes $(4 \mu \mathrm{m})$, regularly arranged. The posterior pair of micraesthetes may be obscured below the granule viewed from above (Fig. 1e). Valves in the type series and other specimens seem prone to erosion of the distal tegmentum.

Articulamentum weakly developed; apophyses broad and short, trapezoidal, widely separated, with a proximal rightangle anterior point, with long, slightly concave slope to jugum (Fig. 1d).

Radula major lateral teeth with long $(45 \mu \mathrm{m})$ unicuspid heads. The central tooth is tall $(24 \mu \mathrm{m})$ with a distinct blade (Fig. 1f).

Girdle appears narrow, dorsally covered in blunt scales with 12 ribs, scales $50-70 \times 40 \mu \mathrm{m}$, longer toward margin and valve interstices (Fig. 1g). At interstices of valves are small clusters of cylindrical spines, usually broken, similar to marginal fringe. Marginal fringe spicules, cylindrical, smooth, blunt, $95 \times 15 \mu \mathrm{m}$ (Fig. 1h). Ventrally, girdle covered in elongate, smooth, flat, bluntly pointed scales $(70 \times 20 \mu \mathrm{m})$, with irregular and barely raised ribs at tip on one side only (Fig. 1i).

Schwabe organ (Sigwart et al. 2011) thin stripe posterior of oral hood.

Gills seven per side, without interspace, extending posteriorly to the anus.

\section{Remarks}

The basic taxonomic features of $L$. cascadiensis sp. nov., summarised above, are only subtly differentiated from those of $L$. rugatus s.s. The similarity of members in this species complex was noted by Ferreira (1979), who considered a number of available names to be junior synonyms of L. rugatus. However, minor differences between the two species can be observed: the granulation of valve sculpture in L. cascadiensis sp. nov. is less dense than in L. rugatus (Fig. 1a, d) and the granules less prominent (Fig. 1e), though these are features that may be plastic to individual environmental conditions. In addition, the valves are somewhat thinner (antero-dorsally), and the apophyses are larger, in L. cascadiensis sp. nov. compared to L. rugatus (Fig. 1a, d). Our conclusion that $L$. cascadiensis sp. nov. represents a valid species and does not correspond to any available names is dependent on these distinctions as part of the total evidence gained from morphology, natural history, and molecular genetic evidence, summarised below.

Leptochiton cascadiensis sp. nov. is most similar to L. rugatus s.s., while examination of the type material of L. alascensis (Thiele, 1909) shows several distinct features (B. Sirenko, pers. comm.). Leptochiton alascensis has carinated valves, while those of $L$. cascadiensis sp. nov. are rounded. In $L$. alascensis, the granules on lateral areas of the tegmentum are arranged in a more random manner (compared to clear radial lines in both L. rugatus and $L$. cascadiensis sp. nov.), the aesthete bulbs have around three pores (vs. groups of five or seven pores in L. rugatus and L. cascadiensis sp. nov.), and dorsal scales are narrower, with 5-8 ribs (vs. 13-16 in L. rugatus and around 12 in L. cascadiensis sp. nov.).

\section{Discussion}

Specimens of Leptochiton cascadiensis sp. nov. were found to be apparently harbouring eggs in the pallial cavity (Fig. 2). We are not able to definitively confirm that the eggs observed 

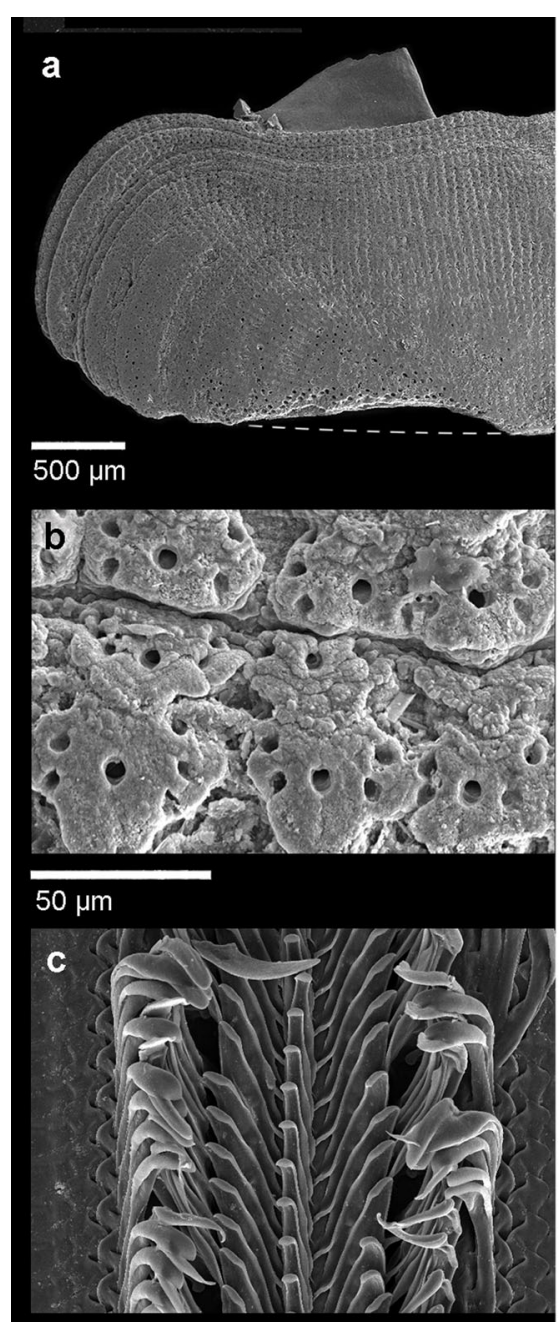

$100 \mu \mathrm{m}$

Leptochiton rugatus
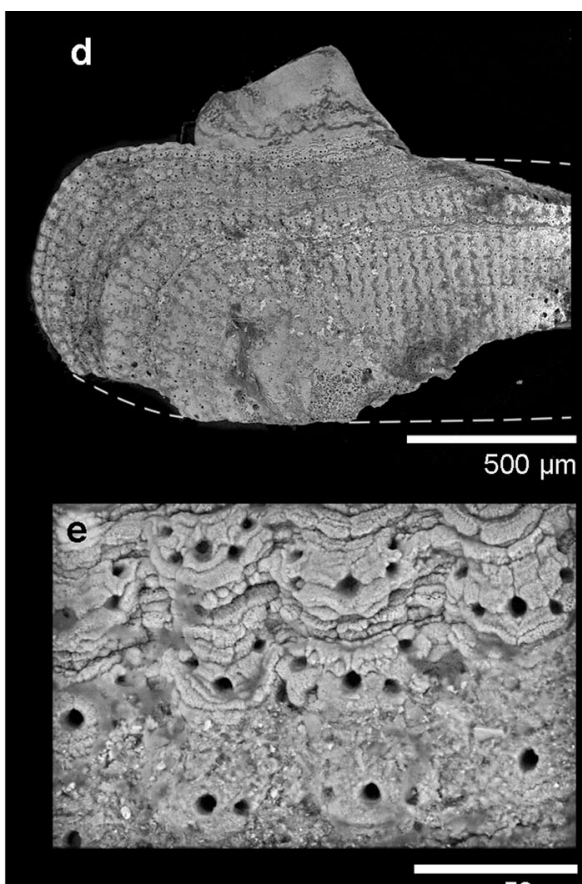

$50 \mu \mathrm{m}$
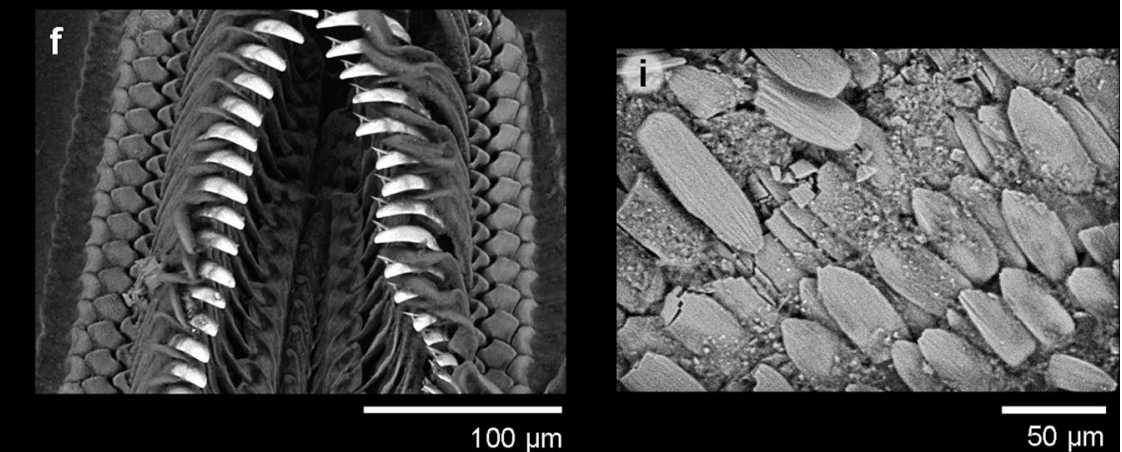

$50 \mu \mathrm{m}$

Leptochiton cascadiensis sp. nov

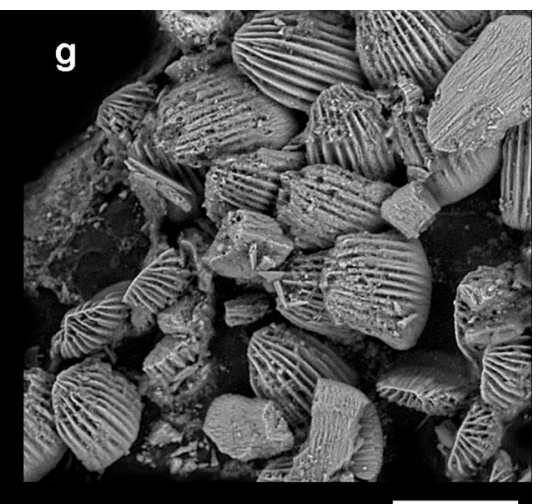

h

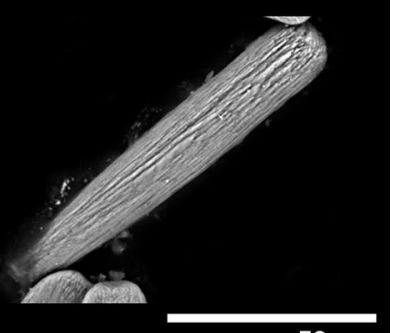

$50 \mu \mathrm{m}$
Fig. 1 Elements illustrating taxonomic features in Leptochiton rugatus (left, RMNH.MOL.K.4616, Pacific Grove, California, USA) and Leptochiton cascadiensis sp. nov. (right, holotype CASIZ 220236, San Juan Island, Washington, USA): valve II with dotted line indicated

were from the chitons, but the circumstantial evidence is nonetheless interesting, so we present it here as a very preliminary observation and a hypothesis subject to further testing. The eggs had a smooth hull, which would be typical of the clade; however, they were around $100 \mu \mathrm{m}$ in diameter, which is very small compared to the usual egg size of at least $200 \mu \mathrm{m}$ reported for other chitons, including other species of the genus Leptochiton. This, and a lack of definitive developmental or genetic evidence to tie the eggs to the adult, leaves us with doubt about their origin. However, the hypothesis is worthy of consideration.

Leptochiton cascadiensis sp. nov., like almost all chitons, is dioecious. As several but not all of the co-occurring specimens we observed had eggs, we could infer that only female individuals were brooding eggs. The eggs were found only in the breakage (a, d, top), valve aesthetes (b, e, middle), and radula (c, f, bottom). At far right, details of girdle elements in L. cascadiensis sp. nov.: $\mathbf{g}$, dorsal scales, $\mathbf{h}$, marginal spine, $\mathbf{i}$, ventral scales

pallial cavity, not elsewhere on the body of the chiton, which is the mode in which brooding chitons keep their eggs. The eggs were not clustered in the form of an egg mass from a parasitic copepod (Avdeev and Sirenko 1991; Fig. 2). Brooding behaviour is known from 41 chitons, including five confirmed species of Leptochiton (Luizzi and Zelaya 2013; Ituarte and Arellano 2016; Sirenko 2015), and may be present in many additional species. It was not apparent whether the eggs were fertilised, and none of them were observed to progress in development. Indeed, they may have been released prematurely in reaction to handling stress on collection. Or, given the preliminary and circumstantial nature of the observation, it may be coincidence.

Brooding behaviour does present a very plausible explanation for previous observations of site fidelity in 
Fig. 2 Photographs and drawings of Leptochiton cascadiensis sp. nov., harbouring putative eggs in the pallial cavity, July 2012, False Bay, San Juan

Island, Washington, USA.

Anterior is at the top in all images; animal length approx. $8 \mathrm{~mm}$
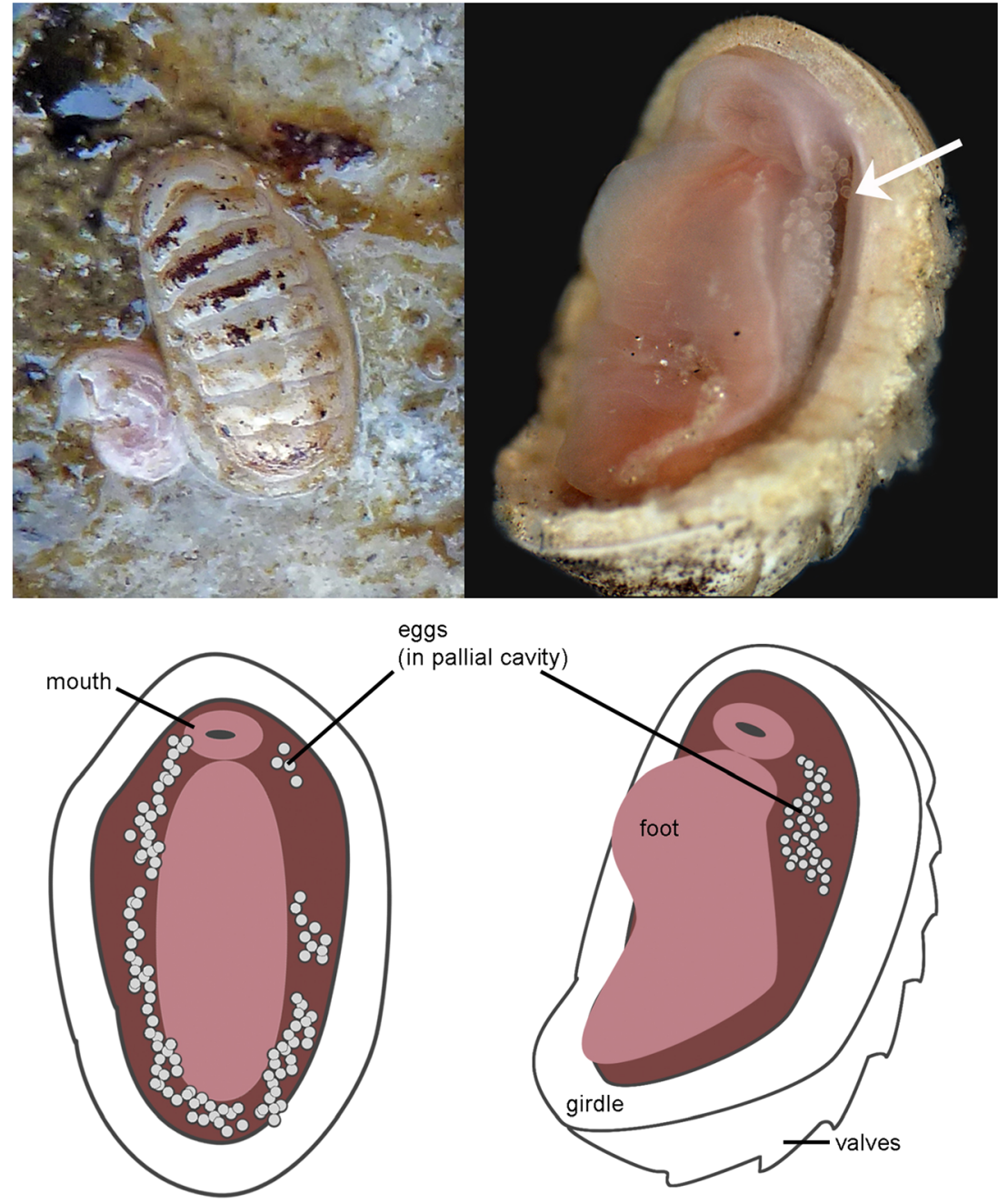

L. cascadiensis sp. nov. (see "Materials and Methods" above). Their patchy distribution is speculatively correlated with very low dispersal potential and larval recruitment, staying primarily in the immediate vicinity of the parent population. The species apparently depends on specific habitat conditions: under-boulder conditions that are stable and undisturbed on a decadal scale (JDS, pers. obs.). Leptochiton cascadiensis sp. nov. lives under rocks that are not tumbled in annual storm events, but also not so embedded as to block chiton-sized access. There are large stretches of the high-energy, exposed coast of Oregon which probably completely lack such habitat, and this would represent a major genetic break in the species complex that correlates to observed patterns (Fig. 3).

Our population genetic analysis identified four distinct non-overlapping haplotype groups corresponding to distinct geographical ranges within the total distribution of the species complex (Fig. 3). This expands upon other studies that have used subsets of the same data, here identifying L. rugatus s.s., L. cascadiensis sp. nov., and two additional populations. All of the sequences included are shallow-water specimens, predominantly collected in the intertidal. The haplotype network also provides some additional evidence as to potential life history strategies of these different species.

The haplotype network of the group corresponding to Leptochiton cascadiensis sp. nov., from southern Alaska, British Columbia, Washington, and Oregon $(n=33)$, contained only four haplotypes. The dominant haplotype was represented in 23 individuals, indicating little genetic variation and haplotype diversity in the populations. The two individuals from Haida Gwaii, British Columbia, shared a haplotype which differed from the dominant haplotype by one step. This homogeneity is not inconsistent with the observation that they are brooders.

On the other hand, the group from Baja California and California $(n=24)$, corresponding to L. rugatus s.s., contained as many as 15 sampled haplotypes, of which 13 were singletons, and a further seven inferred haplotypes. The dominant haplotype was found in nine individuals. No clustering pattern could be seen in haplotype distribution according to locality (Fig. 3); individuals from the three localities in California as well as those form Baja California were well mixed, indicating 


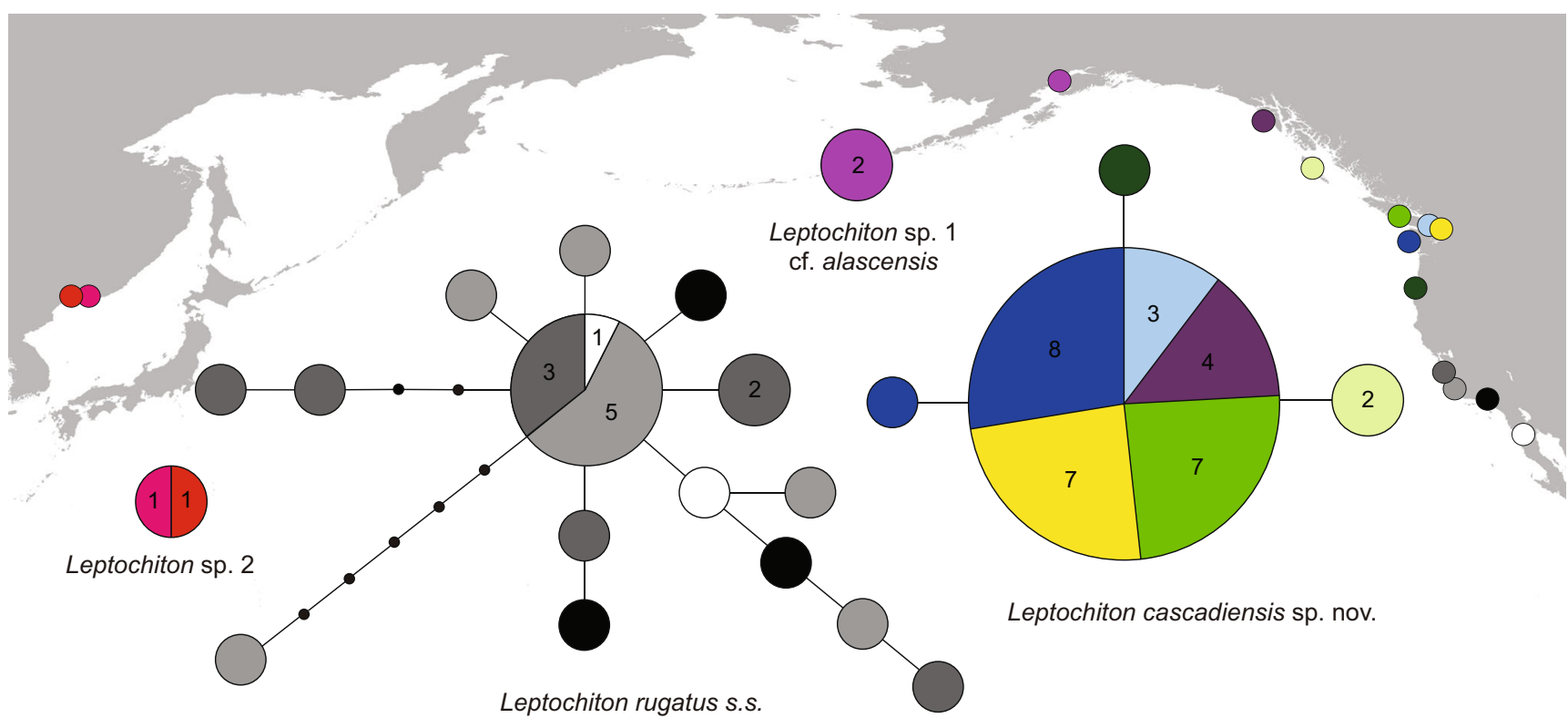

Fig. 3 Haplotype network of the Leptochiton rugatus species complex, reconstructed based on the COI gene. The size of circles and numbers within denote sampled frequency; lack of a number indicates a single specimen. Colours correspond to sampling localities, the approximate positions of which are shown on the map with matching colours

northern coast (e.g. Oldroyd 1927; Dall 1921). The latter name actually refers to a northeast Atlantic species, which is why we have herein renamed it $L$. cascadiensis $\mathrm{sp}$. nov. The distinction between northern and southern populations was lost in later revision.

Several available names were "lumped" as junior synonyms to L. rugatus by Ferreira (1979): Leptochiton alascensis (Thiele, 1909) differs morphologically from the L. cascadiensis sp. nov., Leptochiton assimilis (Thiele, 1909) has a type locality in Russia (Vladivostok) but is considered distinct from the present material (B. Sirenko pers. comm.), Leptochiton cancellatus (Sowerby, 1840) is restricted to the northeast Atlantic and is phylogenetically completely separate from the L. rugatus species complex (Sigwart et al. 2011), Leptochiton internexus (Carpenter in Pilsbry, 1892) geographically overlaps Leptochiton rugatus s.s. and is probably a genuine junior synonym, and Leptochiton rugatus is restricted to California and Mexico. We will consider the members of this species complex in more detail below.

Several older works refer to Leptochiton rugatus as restricted to California and Mexico, and used the name L. cancellatus for specimens from British Columbia and the surrounding region (e.g. Dall 1921; Oldroyd 1927). We believe these records all refer to $L$. cascadiensis sp. nov.; however, there are some deeper-water records which remain in doubt, especially in light of the apparent depth partitioning of $L$. "rugatus" and L. assimilis in the western Pacific (see below). The Atlantic species $L$. cancellatus is superficially somewhat similar to 
L. cascadiensis sp. nov. in that it is small and round-backed, but the two are phylogenetically and phylogeographically unrelated (Sigwart et al. 2011). The epithet L. cancellatus was subsumed in Ferriera's (1979) revision of West Coast lepidopleuran chitons, and this early recognition of separate geographical ranges was temporarily lost.

The two specimens included herein from Cook Inlet, Alaska, were clearly separate from L. cascadiensis sp. nov., and formed their own group. We refer to these specimens as Leptochiton sp. 1. (Fig. 3). The study that originally published these sequence data used the name L. "alascensis" (Layton et al., 2014). This may in fact be the correct identification for those specimens. They clearly differ from L. cascadiensis sp. nov.: Leptochiton sp. 1 is separated by a $10.5 \%$ pairwise difference from the dominant haplotype of $L$. cascadiensis sp. nov. Unfortunately, the specimens were not available, so we have been unable to examine their morphology, and there is some doubt about the actual range of $L$. alascensis as originally described. The type locality of $L$. alascensis is "frühern russisch-amerikanischen Besitzungen (Alaska)", thus not specifically constrained (Thiele, 1909; Kilias 1995). Other older species descriptions referring to "Alaska" in this way, were conflated with the full range of the Russian American territories, extending much further south to San Francisco Bay on the west coast of North America (Clark 2004); the material for L. alascensis was apparently found in the St Petersburg museum in the early twentieth century (Thiele, 1909), so it is not wholly clear whether that type locality was documented before or after the last of these territories was transferred to the US government. We remain cautious as to whether L. alascensis is genuinely Alaskan.

Another of the proposed synonyms, L. assimilis Thiele, 1909, was re-recognised as a separate valid epithet for northwest Pacific populations from a type locality in Vladivostok (Kaas and Van Belle 1994). The two Russian specimens with sequence data included in the present study were originally identified as L. rugatus, distinct from L. assimilis (B. Sirenko, pers. comm.; Sigwart et al. 2011). Leptochiton assimilis occurs in the same area but is found deeper, from 40$60 \mathrm{~m}$, whereas these two specimens, L. sp. 2, were collected at 2-5 m (B. Sirenko pers. comm.). In a more recent phylogeny (Sigwart 2016), the Russian specimens nested within the larger L. rugatus species complex, also including L. cascadiensis sp. nov. and L. rugatus s.s. We recovered only one haplotype from the two Russian specimens, which we refer to as Leptochiton sp. 2. While these specimens apparently are not attributable to $L$. assimilis, they are indisputably outside the range of L. rugatus s.s. as understood from the present results.

We have also examined morphological specimens identified as L. "rugatus" from Vostok Bay (0.5 m depth) and
Korea (Naturalis, Leiden, RMNH.MOL.HLS.1024; Royal Belgian Institute of Natural Sciences, Brussels, RBINS INV 22450), which are also very similar to others from the eastern Pacific. However, extrapolating from the genetic and morphological patterns observed here, it is likely that specimens from Korea may represent yet another additional species, while not necessarily appearing morphologically distinct. Given the morphological conservatism of this clade, it is clear that an integrative approach including morphology and genetics would be required in comparison with $L$. assimilis.

The name L. internexus has a type locality in Santa Barbara, California, and as it is within the geographic range of L. rugatus s.s., we believe it probably is truly an invalid name and a junior synonym of L. rugatus. It is frequently referred to in earlier literature as being similar to L. rugatus but smaller, and with orange-coloured valves (e.g. Oldroyd 1927). The orange colouration could simply be mineral deposits, reflecting local habitat conditions rather than separate identity.

Additional populations, distinct from L. rugatus s.s. and L. cascadiensis sp. nov., probably represent additional undescribed species. Global members of the genus Leptochiton present a limited morphological range, which confounds reconstruction of internal relationships (Sigwart 2009, 2016), although species can generally be easily distinguished by a broad suite of well-established characters (e.g. Kaas and Van Belle 1985). This is evidentially not the case in the L. rugatus species complex, and resolving its species diversity requires a totalevidence approach.

As members of the Leptochiton rugatus s.l. species complex present only subtle morphological variation, determining which name should be applied to which population is not straightforward. We did not attempt to resolve the entire L. rugatus species complex, which would traditionally require examination of the type material of all available names and obtaining molecular and morphological data for all other taxa under consideration. Genetic comparison, consideration of the geographic ranges of other available names, and comparison of our new material with images of type material of L. alascensis was sufficient to determine that Leptochiton cascadiensis sp. nov. is a new species. The information presented here should make future further revisions significantly easier. This type of puzzle is a frequent occurrence in taxonomic revision (Costello et al. 2013b), but assigning names to species is critical to understanding - and conservingbiodiversity.

These distinctions are important, and the lack of up-todate revisionary systematics has created some confusion in the literature. For example, one paper illustrated a specimen of L. cascadiensis sp. nov. (Sigwart et al. 2011: fig. 1B), while actually describing phylogenetic results sampled only from what we refer to herein as Leptochiton sp. 2 
(Sigwart et al. 2011: fig. 2). The specimens we have examined in the L. rugatus species complex present morphological differences that might be considered within the realm of plasticity if compared between individuals. Other coastal invertebrate species, including chitons, from the northeast Pacific are known to be panmictic across very large ranges (e.g. Doonan et al. 2012; Kelly and Palumbi 2010; Kelly et al. 2010; Marko et al. 2010). The new insight into potential brooding behaviour in L. cascadiensis sp. nov. and the inferred limitation on its dispersal potential underscores the probable division of species lineages, upheld by strong genetic separation. Total evidence of dispersal limitation, morphology, and molecular data indicates that these populations are separate species.

Despite speculative limitations on dispersal and local retention, we see little evidence of isolation or drift at small scales within the range of $L$. cascadiensis sp. nov.; however, the sample density presently available is not sufficient for investigating fine structure patterns. The obvious differences in genetic structure between $L$. cascadiensis sp. nov. and L. rugatus may yet indicate differential life history strategies, and a much lower dispersal potential for local populations of L. cascadiensis sp. nov., despite its overall broad range from Oregon to Alaska. The local-scale isolation and patchiness of L. cascadiensis $\mathrm{sp}$. nov. raises concern that any further intensive destructive sampling could inadvertently obliterate a local population. Occasional events (e.g. storms) that transport individuals between adjacent populations could be sufficient to maintain genetic mixing, even if these occur at multi-generational scales (Bryan et al. 2012). But if a population is removed, this could create a significant barrier to longer-term long-distance dispersion.

These chiton species are relatively common, broadly distributed members of the low intertidal to subtidal communities in the northeast Pacific coast. Leptochiton cascadiensis sp. nov. is relatively difficult to find, only because of their extreme site fidelity and patchy distribution, now understood to be probably related to their unusual life history. This case study presents another example where a study of familiar intertidal species reveals a cryptic species complex, and a conservation imperative to recognise separate regional species.

\footnotetext{
Acknowledgements We thank the director and staff of Friday Harbor Laboratories, University of Washington. We are grateful to a number of colleagues who contributed to this work: Nathan Lee (UW) and Richard Emlet (OIMB, Charleston, OR) assisted with fieldwork. Svetlana Maslakova (OIMB) collected the specimen from Oregon. Nicole Moss (OIMB), Ken Nagata (JAMSTEC) and Dr. Hiromi Watanabe (JAMSTEC) helped with sequencing. Boris Sirenko (ZISP, St Petersburg) provided images of the type material of L. alascensis and reviewed an earlier version of this article. A second anonymous reviewer also provided comments that improved this paper. Jeroen Goud (RMNH Naturalis), Terry Gosliner (CalAcademy) and Jackie Van Goethem (RBINS) facilitated access to collections. Finally, we also thank Dr. Leigh Marsh (U Southampton) for discussion and assistance with figures
}

and Dr. Ken Takai (JAMSTEC) for facilities that supported analysis and writing.

\section{Compliance with ethical standards}

Funding This research was supported by the European Commission award H2020-MSCA-IF-2014-655661 to JDS, and additional data obtained via the SYNTHESYS access to infrastructure programme for JDS' travel to RMNH Naturalis and to RBINS.

Conflict of interest The authors declare that they have no conflict of interest.

Open Access This article is distributed under the terms of the Creative Commons Attribution 4.0 International License (http:// creativecommons.org/licenses/by/4.0/), which permits unrestricted use, distribution, and reproduction in any medium, provided you give appropriate credit to the original author(s) and the source, provide a link to the Creative Commons license, and indicate if changes were made.

\section{References}

Avdeev GV, Sirenko BI (1991) Chitonophilidae fam-n, a new family of parasitic copepods from the chitons of the North-western Pacific. Parazitologiya 25(4):370-374

Berry SS (1927) Notes on some British Columbia chitons. Proc Mal Soc London 17:1-36

Berry S (1951) Notes on some British Columbia chitons II. Proc Mal Soc London 28:213-229

Bryan SE, Cook AG, Evans JP, Hebden K, Hurrey L, Colls P et al (2012) Rapid, long-distance dispersal by pumice rafting. PLoS ONE 7(7), e40583

Carey N (2014) Metabolism and metabolic scaling in marine invertebrates: the effects of temperature and ocean acidification. $\mathrm{PhD}$ thesis, School of Biological Sciences, Queen's University, Belfast

Carey N, Galkin A, Henrikkson P, Richards J, Sigwart JD (2012) Variation in oxygen consumption among 'living fossils' (Mollusca: Polyplacophora). J Mar Biol Assoc UK 93:197-207

Clark RN (2004) On the identity of von Middendorff's Chiton sitchensis and Chiton scrobiculatus. Festivus 36(5):49-52

Clement M, Posada D, Crandall K (2000) TCS: a computer program to estimate gene genealogies. Mol Ecol 9:1657-1660

Costello MJ, May RM, Stork NE (2013a) Can we name Earth's species before they go extinct? Science 339:413-416

Costello MJ, Bouchet P, Boxshall G, Fauchald K, Gordon D, Hoeksema BW et al (2013b) Global coordination and standardisation in marine biodiversity through the World Register of Marine Species (WoRMS) and related databases. PLoS ONE 8(1), e51629

Dall WH (1921) Summary of the marine shellbearing mollusks of the northwest coast of America, from San Diego, California, to the Polar Sea, mostly contained in the collection of the United States National Museum, with illustrations of hitherto unfigured species. US Nat Mus Bull 112:1-217

Dell'Angelo B, Bonfitto A, Taviani M (2011) Chitons (Polyplacophora) from Paleogene strata in western Washington State, U.S.A. J Paleontol 85:936-954

Doonan J, Beatty G, Sigwart JD, Provan J (2012) Extensive local-scale gene flow and long-term population stability in the intertidal mollusc Katharina tunicata (Mollusca: Polyplacophora). Biol J Linn Soc 106:589-597 
Ferreira AJ (1979) The family Lepidopleuridae (Mollusca: Polyplacophora) in the Eastern Pacific. Veliger 22:145-165

Ituarte C, Arellano FE (2016) Structural study of the ovary, oogenesis and brooding in Tonicia lebruni (Polyplacophora Chitonidae) from Patagonia. Acta Zoologica (Stockholm) 97:494-505. doi:10.1111/ azo. 12142

Kaas P, Van Belle RA (1985) Monograph of living Chitons (Mollusca: Polyplacophora), volume 1. Order neoloricata, lepidopleurina. Backhuys, Leiden

Kaas P, Van Belle RA (1994) Monograph of living chitons (Mollusca: Polyplacophora), volume 5. Suborder ischnochitonina: ischnochitonidae: ischnochitoninae (concluded), callistoplacinae; mopaliidae; additions to volumes 1-4. Backhuys, Leiden

Kelly RP, Eernisse DJ (2007) Southern hospitality: a latitudinal gradient in gene flow in the marine environment. Evolution 61:700-707

Kelly RP, Palumbi SR (2010) Genetic structure among 50 species of the Northeastern Pacific rocky intertidal community. PLoS ONE 5, e8594

Kelly RP, Oliver TA, Sivasundar A, Palumbi SR (2010) A method for detecting population genetic structure in diverse, high gene-flow species. J Hered 101:423-436

Kilias R (1995) Polyplacophora-Typen und -Typoide (Mollusca) im Zoologischen Museum in Berlin. Mitt Zool Mus Berl 71:155-170

Knowlton N (1993) Sibling species in the sea. Annu Rev Ecol Syst 24: $189-216$

Lamb A, Hanby B (2005) Marine life of the Pacific Northwest. Harbour Publishing, Vancouver

Layton KKS, Martel AL, Hebert PDN (2014) Patterns of DNA barcode variation in Canadian Marine Molluscs. PLoS ONE 9(4), e95003

Luizzi MG, Zelaya DG (2013) Egg-hull ultrastructure of Ischnochiton stramineus (Sowerby, 1832), a South American brooding chiton (Chitonina: Ischnochitonidae). J Molluscan Stud 79:372-377

Marko PB, Hoffman JM, Emme SA, McGovern TM, Keever CC, Cox NL (2010) The 'Expansion-Contraction' model of Pleistocene biogeography: rocky shores suffer a sea change? Mol Ecol 19:146-169

Newcombe CF (1893) Report on the marine shells of British Columbia. Bull Nat Hist Soc Br Columbia 1893:31-72
Oldroyd IA (1927) The marine shells of the West Coast of North America. Stanford University Press, Palo Alto

Riedel A, Sagata K, Suhardjono YR, Tänzler R, Balke M (2013) Integrative taxonomy on the fast track - towards more sustainability in biodiversity research. Front Zool 10:15

Sigwart JD (2009) Primitive living chitons: morphological cladistic analysis as a model for character evaluation. Am Malacol Bull 27:95-104

Sigwart JD (2016) Deep trees: woodfall biodiversity dynamics in present and past oceans. Deep Sea Res Part II. doi:10.1016/j. dsr2.2016.06.021

Sigwart JD, Schwabe E, Saito H, Samadi S, Giribet G (2011) Evolution in the deep sea: combined analysis of the earliest-derived living chitons using molecules and morphology (Mollusca, Polyplacophora, Lepidopleurida). Invertebr Syst 24:560-572

Sigwart JD, Sumner-Rooney L, Schwabe E, Hess M, Brennan G, Schroedl M (2014) A new sensory organ in "primitive" molluscs (Polyplacophora: Lepidopleurida), and its context in the nervous system of chitons. Front Zool 11:7

Sirenko BI (2015) The enigmatic viviparous chiton Calloplax vivipara (Plate, 1899) (Mollusca: Polyplacophora) and a survey of the types of reproduction in chitons. Russ J Mar Biol 41(1):24-31

Sumner-Rooney LH, Murray JA, Cain SD, Sigwart JD (2014) Do chitons have a compass? Evidence for magnetic sensitivity in Polyplacophora. J Nat Hist 48:3033-3045

Vendrasco MJ, Eernisse DJ, Powell CLI, Fernandez CZ (2012) Polyplacophora (Mollusca) from the San Diego Formation: a remarkable assembalge of fossil chitons from the Pliocene of Southern California. Nat Hist Mus Los Angel County Contrib Sci 520:15-72

Whiteaves JF (1887) On some marine invertebrates dredged or otherwise collected by Dr G.M. Dawson in 1885, in the northern part of the Strait of Georgia, in Discovery Passage, Johnstone Strait, and Queen Charlotte and Quatsino Sounds, British Columbia; with a supplementary list of a few land and fresh water shells, fishes, birds, etc., from the same region. Trans R Soc Can 1886:111-137 